\title{
A FUSÃO DE HORIZONTES NA ANÁLISE TEXTUAL DISCURSIVA
}

\section{THE FUSION OF HORIZONS IN THE DISCURSIVE TEXTUAL ANALYSIS}

\author{
Maria do Carmo Galiazzi ${ }^{1}$ \\ Valderez Marina do Rosário Lima \\ Maurivan Güntzel Ramos ${ }^{3}$
}

\begin{abstract}
Resumo: As discussões sobre metodologia têm se tornado muito presentes nos programas de pósgraduação. Este artigo foca a Análise Textual Discursiva - ATD e apresenta a partir da trajetória dos autores as formas como a metodologia foi conceituada e implementada por Roque Moraes. $\mathrm{O}$ artigo apresenta o movimento histórico do desenvolvimento do ATD a partir da Análise de Conteúdo em seu início e como, inspirada na Fenomenologia de Husserl, na Complexidade de Morin, tem se encaminhado para a Hermenêutica. Conhecer as teorias que sustentam a ATD possibilitará uma maior compreensão das formas como a ATD impacta o pesquisador e o desenvolvimento de pesquisas qualitativas. Uma estrutura conceitual é proposta para permitir aos pesquisadores descrever as condições de usos de DTA a partir de argumentos teóricos.
\end{abstract}

Palavras-chave: Metodologia; Fenomenologia; Hermenêutica; Complexidade.

Abstract: Discussions about methodology have become commonplace in postgraduate programs. This paper focuses on the Discursive Textual Analysis (DTA) and shows how the methodology was conceptualized and implemented by Roque Moraes, from the perspectives of the authors' journeys. It introduces the historical movement of DTA development, based on the Content Analysis at its beginning and how, inspired by Husserl's Phenomenology and Morin's Complexity, it has been moving towards Hermeneutics. Knowing the theories which support the DTA enables better understanding of the ways in which it impacts researchers and the development of qualitative studies. A conceptual framework is proposed to enable researchers to describe the conditions of use of the DTA based on theoretical arguments.

Keywords: Methodology; Phenomenology; Hermeneutics; Complexity.

\section{Introdução}

Neste texto, apresentamos a Análise Textual Discursiva (ATD) (2007) como metodologia ${ }^{4}$ de análise, inserida em um campo que busca a compreensão de fenômenos

\footnotetext{
${ }^{1}$ Doutora em Educação, Pontifícia Universidade Católica do Rio Grande do Sul (PUCRS), Universidade Federal do Rio Grande - FURG (FURG), Rio Grande, Rio Grande do Sul, Brasil. E-mail mariagaliazzi@furg.br

${ }^{2}$ Doutora em Educação, Pontifícia Universidade Católica do Rio Grande do Sul (PUCRS), Pontifícia Universidade Católica do Rio Grande do Sul (PUCRS), Porto Alegre, Rio Grande do Sul, Brasil. E-mail valderez.lima@pucrs.br

${ }^{3}$ Doutor em Educação, Pontifícia Universidade Católica do Rio Grande do Sul (PUCRS), Pontifícia Universidade Católica do Rio Grande do Sul (PUCRS), Porto Alegre, Rio Grande do Sul, Brasil. E-mail mgramos@pucrs.br

${ }^{4}$ Consideramos ATD uma metodologia, acompanhando o argumento de Bicudo (2011, p. 11), que afirma que, na descrição dos procedimentos de pesquisa, as dimensões ontológicas, epistemológicas e metodológicas precisam ser consonantes. "É nesta trama tecida por tais considerações que o lógos, entendido como pensamento articulador que se doa à inteligibilidade, presente na palavra metodologia, evidencia-se, diferenciando-a de método".
} 
sob uma perspectiva qualitativa de pesquisa, com ancoragem em pressupostos da Fenomenologia, da Complexidade e da Hermenêutica. Abarcar esse objetivo é uma tarefa desafiadora. Claramente, este artigo não dá conta de alcançar uma discussão ampla e densa, em razão de tempos e espaços vividos. Pretendemos, no entanto, destacar situações de experiências em nossa formação como pesquisadores, apresentando elementos que resultaram na elaboração da ATD e como temos buscado compreendê-la e discuti-la em cursos de pós-graduação. Colocamos em destaque lembranças de encontros e práticas vividas no mestrado e no doutorado, em que disciplinas, grupos e livros nos levam a interpretar sentidos trazidos nos percursos de Roque Moraes na Fenomenologia, na Hermenêutica, na Análise de Conteúdo, na pesquisa qualitativa, resultando no aparecimento da ATD.

O texto apresenta uma visão sincrética do processo de Análise Textual Discursiva, a partir das elaborações teóricas efetuadas no decorrer de nossos percursos de formação acadêmica e profissional. Em que pese a intensa parceria, a escrita é multifacetada com as expressões de cada um de nós, ora configuradas em diálogos, ora por intermédio de inserções teóricas ou, ainda, por meio de sistematizações das ideias apresentadas. Consoante com uma das metáforas presentes na obra sobre Análise Textual Discursiva, delineamos o texto em forma de mosaico, no qual inserimos peças distintas, pois cada um de nós, autores, tem sua história. O resultado compõe-se em um todo harmonioso. Ao longo do artigo, o nome de cada um dos autores aparece entre parênteses, antes de sua manifestação, e a forma replica o modo como Roque Moraes sinalizou a fala dos entrevistados em seu relatório de pesquisa de doutoramento ${ }^{5}$. Utilizar o mesmo formato foi uma maneira de ter nosso orientador junto conosco no texto. É, pois, uma homenagem a ele.

O artigo encontra-se organizado em cinco partes, que transitam entre histórias e constructos teóricos, explicitando as compreensões assumidas da Análise Textual Discursiva em nossa prática de pesquisadores. A primeira parte, (1) Lembranças de formação em pesquisa, é instigada pela pergunta: podemos começar a rememorar?

\footnotetext{
${ }^{5} \mathrm{Na}$ tese de doutorado, Roque Moraes entrevistou professores de Ciências e, no relatório, organizou essas entrevistas como uma conversa. O grupo de professores foi intencionalmente selecionado. As entrevistas foram não estruturadas, com a convicção de que um relacionamento mais espontâneo e não direcionado possibilitaria atingir maior profundidade e riqueza de informações. A pergunta que orientou a entrevista foi: como você se tornou o professor que atualmente é? Cada entrevista foi analisada separadamente, tendo identificadas as unidades de significado intermediárias e sendo reescritas em linguagem educacional. Posteriormente, as análises de cada entrevista foram reunidas em unidades globais de significado. Para apresentar parte dos resultados da análise, Roque Moraes decidiu organizar uma entrevista coletiva, e é no modo como a apresenta na tese que nos espelhamos para conversar neste texto.
} 
Maurivan inicia narrando o encontro de Roque Moraes com a pesquisa qualitativa, e Maria do Carmo apresenta suas reflexões, propondo à Valderez que também o faça. Na segunda parte, (2) O educar pela pesquisa e a escrita como modo de pensar, a pergunta que desencadeia o relato é: tivemos uma vivência e conversamos muito sobre o educar pela pesquisa naqueles tempos de pesquisa juntos, lembram? Esse questionamento vai sendo respondido pelos três autores por meio de descrições de experiências e exemplos de pesquisas realizadas. Na parte seguinte, (3) A escrita no coletivo como modo epistêmico de pesquisa, o diálogo é estruturado em torno da pergunta: de que modo a escrita coletiva teve influência na compreensão da ATD? Nessa seção, Maria do Carmo e Maurivan narram vivências de escrita coletiva e apontam a importância desse exercício para reconstruções teóricas e aprofundamento de compreensão sobre conceitos e fenômenos estudados. Na quarta parte, (4) O encontro com a Fenomenologia e com a Hermenêutica Filosófica, a questão norteadora é: como a Fenomenologia representou uma visão distinta sobre fazer ciência para Roque? Como ele afirma, o encontro com a Fenomenologia foi o despertar de uma nova visão. O que se destaca desse encontro? Neste caso, foi orientador para Maria do Carmo tecer a narrativa de encontro da Fenomenologia com a Análise Textual Discursiva, na perspectiva de Roque Moraes, idealizador da metodologia de análise e de seu movimento em direção à Hermenêutica. Este movimento se mostra na presença do círculo hermenêutico em Moraes (1991, 2019), movimentandose para a pertinência da metáfora (RICOEUR, 2000) e para a Hermenêutica Filosófica (GADAMER, 2004) em sua potência ontológica. Na quinta parte, (5) A fusão de horizontes para um reinício, seção final, tal como na ATD, expressamos o ponto final do artigo e acenamos com as potencialidades para a construção de um próximo ciclo.

\section{Lembranças de formação na pesquisa}

Podemos começar a rememorar?

\section{(Maurivan)}

O doutorado do Prof. Roque Moraes foi realizado de 1985 a 1991. Foi nessa época que se descobriu na pesquisa qualitativa. Contribuiu para isso uma primeira pesquisa que realizamos, cujos resultados foram publicados em duas partes na revista Educação, da PUCRS: uma em 1985 e outra em 1986. O primeiro artigo tratou de características de professores do Ensino de Química no $3^{\circ}$ grau; o segundo tratou da análise de problemas 
de ensino de docentes de Química de $3^{\circ}$ grau e promoveu uma integração com o primeiro, pois os resultados foram complementares. Em ambos os artigos, os respondentes foram licenciandos de Química, e os dados foram tratados pela Análise de Conteúdo. Entretanto, nesses trabalhos, já foram empregados agrupamentos sucessivos de categorias, até chegarmos a categorias gerais, que eram emergentes, sem usarmos esse conceito.

\begin{abstract}
A estratégia de análise utilizada mostrou-se bastante eficiente e funcional. Procurou-se evitar um quadro de classificação prévio, em que se tentasse ajustar os comportamentos. Deixou-se que as categorias fossem surgindo dos próprios dados. Nesse processo foi muito útil a estratégia de organização gradual de categorias mais abrangentes, descritas aqui em três níveis de categorização. O produto desta ordem crescente de abrangência pareceu traduzir as opiniões dos alunos acerca dos problemas de ensino dos professores de Química de $3^{\circ}$ grau (RAMOS; MORAES, 1986, p. 91).
\end{abstract}

Após oito anos dessa publicação, iniciei o doutorado em Educação, na PUCRS, sob a orientação do prof. Roque. O foco era a avaliação qualitativa de professores, na qual trabalhei com a Análise de Conteúdo para, junto com os participantes da pesquisa, em uma ação colaborativa, analisar o que os estudantes dos cursos de Química e Licenciatura em Química diziam do trabalho realizado em suas aulas. Posteriormente, entrevistei cinco docentes sobre o processo vivenciado. As transcrições das entrevistas foram tratadas pela Análise de Discurso, tendo por teoria forte as posições de Jürgen Habermas. Para compreender as diferenças entre essas duas metodologias, produzi um texto contendo metáforas: vendo com os olhos fechados e o voo da águia.

\footnotetext{
Pela dificuldade de entender as diferenças entre estas metodologias, tive de lançar mãos de artifícios que costumo usar em situações como esta. Passei a escrever, criando analogias e metáforas, para tornar mais claras as semelhanças e as diferenças. Era necessário tornar mais concreto o que para mim era abstrato. Para isso utilizei o artifício das metáforas, o que me possibilitou maior compreensão sobre as metodologias empregadas neste trabalho. Mais tarde vim a compreender essa iniciativa lendo Marques (1997), quando faz considerações sobre o papel da imaginação, das metáforas e das analogias na criação de textos (RAMOS, 1999, p.46).
}

Desde as primeiras pesquisas já referidas e durante esse tempo de doutorado, o professor Roque escreveu o artigo sobre Análise de Conteúdo (MORAES, 1999), distanciando-se gradativamente das ideias quantitativas de Bardin (1977) e assumindo a pesquisa qualitativa, na perspectiva fenomenológica. Todavia, não se pode falar em Análise de Conteúdo de Roque Moraes, como já ouvi de professores e alunos. O que ele fez foi o que fazia quando queria compreender algo: escrever sobre. Aprendemos isso com ele. Neste caso, ao escrever sobre Análise de Conteúdo, o seu olhar e o seu texto passaram a carregar uma reinterpretação dessa metodologia de análise. Havia sido influenciado pela Fenomenologia, afastando-se do sentido original. 
Durante esse tempo de doutorado, muito se escreveu e se refletiu com Roque, no grupo de pesquisa, sobre metodologias de pesquisa, nascendo as bases da ATD. Maria do Carmo detalha esse processo.

\section{(Maria do Carmo)}

Cheguei à Pontifícia Universidade Católica do Rio Grande do Sul (PUCRS) no mestrado, em razão de projetos de formação de professores de Ciências desenvolvidos sob coordenação do Prof. Roque Moraes. Ele foi meu orientador de mestrado e também de doutorado. As disciplinas que discutiram metodologias de pesquisa abarcavam, pelo que lembro, discussões acaloradas sobre etnografia, pesquisa-ação e pesquisa participante, entre outros tópicos. Para realização da pesquisa de mestrado, que tratou de concepções epistemológicas de professores de Ciências, e isso foi em 1995, entrevistei professoras e observei muitas salas de aula. Exercia a docência em Química Orgânica na Universidade Federal do Rio Grande (FURG) e entendia muito menos do que atualmente os sistemas educativos públicos da Educação Básica e do Ensino Superior. Havia sido professora de Ciências em escola pública no Bairro Estância Velha, em Canoas, enquanto estudante de Química, e depois, com a vinda para Rio Grande, em uma escola católica de Irmãs de São José, que me acolheram por eu ter sido aluna em Veranópolis, onde cursei do Jardim de Infância ao Ginásio em escola da mesma congregação.

Penso que é importante ressaltar que o que me levou ao mestrado em Educação foi uma palestra da Dra. Maria Helena Menna Abrahão na FURG, por ela contar sua história como professora de Inglês em turmas noturnas, possivelmente na Educação de Jovens e Adultos. Isso, para mim, fazia muita diferença; mais tarde, como aluna da mesma professora, chamava-me a atenção seu modo de destacar as experiências dos sujeitos, o que hoje, olhando para esse tempo todo, me mostra a aproximação com a pesquisa narrativa desde lá. Entretanto, a meu orientador atribuo a decisão de pesquisar em Educação em Ciências, por seu jeito de ensinar, que a poucas perguntas respondia e que a cada uma delas mais algumas acrescentava. Estava eu lá nas aulas de Metodologia de Pesquisa do primeiro semestre.

Em nossas discussões, sempre estava a palavra paradigma, presente no livro Paradigmas e Metodologias de Pesquisa em Educação: notas para a reflexão (ENGERS, 1994). Eram estes alguns dos autores e algumas das proposições paradigmáticas estudadas: Thomas Kuhn, Popper, Anarquismo Epistemológico, Paradigma Positivista, Paradigma Construtivista e certas metodologias da pesquisa qualitativa, como as ideias 
de Egon Guba, abordagem etnográfica na pesquisa educacional, Fenomenologia e Análise de Conteúdo. Acompanhava-me, nas viagens semanais de Rio Grande a Porto Alegre, o pesado Manual de Pesquisa Qualitativa (DENZIN; LINCOLN, 1994), abordando especialmente paradigmas interpretativos e críticos em oposição ao positivismo. Em versão atualizada e revigorada, os mesmos autores afirmam que a intenção, desde lá, foi mostrar a pesquisa qualitativa para auxiliar a pensar em um mundo mais livre e democrático (DENZIN; LINCOLN, 2006).

No Brasil, Minayo (2018) aponta que:

[...] a primeira pesquisa qualitativa da qual se há registro fez parte de um "Estudo Nacional de Despesas Familiares" (ENDEF), ocorrido entre 19741979, com uma amostra de 55 mil domicílios em todo o território nacional e suas regiões, tendo sido entrevistadas e observadas 53.311 famílias. A parte qualitativa do estudo foi realizada a partir dos cadernos de campo dos 1200 agentes (dos 30.000 que atuaram nas atividades empíricas) que fizeram anotações pessoais numa página disposta ao final do caderno de pesquisa, sobre aspectos não previstos no questionário e sobre suas próprias impressões a respeito da situação dos entrevistados.

Como a autora assinala, a origem foi paradoxal, pois foi no Instituto Nacional de Geografia e Estatística (IBGE), responsável pela pesquisa quantitativa.

No segundo semestre, as aulas de Metodologia de Análise. O professor foi Roque Moraes. Lembro-me de discutir textos sobre o paradigma construtivista. Um dos textos discutidos trazia a ideia de círculos de pesquisa, de recursividade e, ao mesmo tempo, de movimento, e isso remete ao círculo hermenêutico, que vou encontrar posteriormente na ATD.

Essas e outras disciplinas inseriram-nos como pesquisadores na pesquisa qualitativa, em oposição à pesquisa quantitativa. Iniciado na década de 70 e intensificado na década de 90, não havia ceticismo em relação à importância do movimento como forma radical de produzir pesquisa. De lá para cá, os paradigmas deslocaram-se para perspectivas interpretativas específicas, feminismos, sexualidade, teoria queer (DENZIN; LINCOLN, 2006). Desde lá, também há posições em direção a pesquisas pós-qualitativas (St PIERRE, 2018).

Voltando à pesquisa de mestrado, chegada a hora de entrevistar as professoras, a orientação foi uma entrevista fenomenológica. Com esse referencial, fui às entrevistas querendo saber o que as professoras pensavam sobre aprendizagem. Iniciava com a pergunta que considerava aberta: o que tu compreendes por aprendizagem? Os resultados foram frustrantes, pois as respostas eram teóricas: os nomes de Piaget e Vygotsky eram mencionados em palavras dirigidas a uma pesquisadora iniciante, e as professoras 
experientes logo tomaram o fio da entrevista. Na reunião semanal, desapontada, contei para meu orientador que as entrevistas mostravam o que as professoras guardavam de argumentos teóricos estudados na graduação e que suas salas de aula pouco apareciam. Fui orientada a substituir a pergunta por uma solicitação: me conta tua última aula! Ao lembrar-me do ocorrido, atento para o modo fenomenológico presente na compreensão de que o fenômeno se mostra (BICUDO, 2000, 2011). Nessa abordagem de descrever uma situação vivida - no caso, a aprendizagem -, é preciso desconsiderar as teorias de aprendizagem, como citaram as professoras; ao pesquisar fenomenologicamente, deve-se ficar atento ao que se mostra nos dizeres (GIORGI, 2014). A partir de um olhar fenomenológico, minha experiência de frustração indicava minha intencionalidade de pesquisa (CERBONE, 2014).

Encontrei também em Moraes $(1991,2019)$ a pergunta aberta aos professores: como cada um de vocês se tornou o professor que atualmente é?

Com as entrevistas da pesquisa de mestrado em andamento, foi iniciada a análise, pois a orientação era iniciá-la ao mesmo tempo em que outras entrevistas eram feitas. $\mathrm{O}$ objetivo desse procedimento era perceber outras perguntas possíveis a serem feitas nas entrevistas ainda não realizadas (MORAES, 1991, 2019). Havia duas metodologias clássicas de análise em discussão no programa de pós-graduação: Análise de Conteúdo, segundo Laurence Bardin, e Análise de Discurso, conforme os pressupostos de Jürgen Habermas. Segui a Análise de Conteúdo, baseando-me na vasta e reconhecida experiência de meu orientador nessa metodologia. Destaco alguns aspectos do artigo intitulado "Análise de Conteúdo" (MORAES, 1994) para articular sua experiência ao que posteriormente passou a ser ATD.

A Análise de Conteúdo foi apresentada como uma técnica de exame de dados e informações de pesquisa em ampla divulgação e uso nas pesquisas em Educação. Foi definida como uma técnica voltada à descrição objetiva, sistemática e quantitativa do conteúdo manifesto. Para Bardin (1977), a Análise de Conteúdo visava à descrição objetiva do conteúdo das mensagens. Pretendia a análise, segundo a autora, produzir inferências em relação às condições de produção ou recepção das mensagens. A ideia de produção de inferências reproduzíveis e válidas também estava presente em Krippendorff (1990).

Segundo Moraes (1994), a Análise de Conteúdo distanciava-se de pressupostos positivistas, voltando-se mais à compreensão. Com isso, apareciam possibilidades de análise para atingir o conteúdo manifesto e o conteúdo latente e que eram questionadas 
as hipóteses que implicavam relações causais. A ausência de hipóteses encaminhava também para a compreensão. A subjetividade passava a ser apontada como necessária. Havia um claro deslocamento no entendimento da Análise de Conteúdo, mas mantinhase a intenção de, mais do que atingir objetivos descritivos, alcançar inferências para chegar à interpretação.

O autor afirmava que a técnica era versátil e adaptável, salientando que o paradigma adotado pelo pesquisador orientaria as possibilidades e limites no seu uso. Como técnica, poderia estar em estudos fenomenológicos, dialéticos e etnográficos, e os deslocamentos da Análise de Conteúdo tradicional eram ressaltados: do conteúdo manifesto para o conteúdo latente, da análise quantitativa para a análise qualitativa, da testagem de hipóteses para a compreensão de um fenômeno, dos significados aos

significantes. Quanto aos objetivos, o movimento era de objetivos descritivos a inferências e interpretações, e do rigor da objetividade estendia-se para a fecundidade da subjetividade.

A posição assumida pelo autor, se indica movimento em direção à compreensão e interpretação, mostra permanências em que se produzem inferências, palavra mais próxima de operações como generalização e quantificação. Também, como técnica, havia uma generalização para diferentes epistemologias. Existia, ainda, um diálogo entre o paradigma construtivista e a Fenomenologia.

Concluindo, na dissertação de mestrado, assumi a pesquisa qualitativa em um paradigma construtivista com análise baseada na Análise de Conteúdo (MORAES, 1994). Não percebi o pertencimento, atualmente claro, de Roque Moraes à Fenomenologia.

E do mestrado veio o doutorado a partir de 1997.

E desse tempo de mestrado e doutorado, Valderez, o que lembras e destacas?

(Valderez)

O encontro com a pesquisa qualitativa! E, por decorrência, o encontro outra lógica de análise, distanciada da análise estatística com a qual estava acostumada. Ao longo de quase 20 anos, havia trabalhado com pesquisas com meus alunos da Educação Básica e orientado professores em elaboração de projetos com vistas a participações em feiras e clubes de Ciências, mas a perspectiva de pesquisa era incondicionalmente alinhada ao paradigma tradicional. O ingresso no mestrado colocou-me em contato com uma forma de produção científica até então desconhecida. A intensa discussão epistemológica que permeava as disciplinas e grupos de pesquisa do PPGEDU/ PUCRS na ocasião levou-me 
da condição de absoluta certeza sobre como pesquisar ao caos e à incerteza, colocando em suspenso minhas convicções.

Foram muitos os inspiradores da reconstrução que lá se iniciou, e, além dos diálogos reflexivos com professores e colegas, muito me influenciaram os estudos do livro de Robert Bogdan e Sari Bicklen (1985), obra que revisito até hoje, cujo impacto foi, principalmente, colocar-me a refletir sobre a produção de conhecimentos no âmbito das Ciências Sociais. A leitura incitava-me com afirmações sobre análise qualitativa, como "não abdique de pensar só porque ainda não possui provas" (p. 219) ou "não tenha medo de especular". O estudo aprofundado do livro Paradigmas e Metodologias de Pesquisa em Educação: notas para a reflexão (ENGERS, 1994), mencionado por Maria do Carmo e muito utilizado no PPGEDU, na ocasião, ao apresentar-me o paradigma naturalístico, ou construtivista, de Lincoln e Guba (1985), convenceu-me da impossibilidade de relações causais, lineares, entre os múltiplos aspectos dos fenômenos sociais e lançou-me ao encontro da análise qualitativa naquele final do século XX.

A dissertação versou sobre Clubes de Ciências, mas no relatório não assumi claramente um tipo específico de análise, embora tenha informado que os procedimentos de descrição/análise/interpretação se ancoraram nas ideias de Olabuenaga e Ispizua (1989) e de Moraes (1994), que constituem uma continuidade dos estudos de Bardin (1977). Uma continuidade... Não uma ruptura. Percebo hoje ter sido esse um deslocamento importante em minha trajetória de pesquisadora.

No doutorado, já assumida a pesquisa qualitativa, a intenção foi aprofundar os estudos, especialmente em nível metodológico. Foram importantes a leitura e a discussão das obras de Edgar Morin, especialmente $O$ método $I$ - A natureza da natureza e $O$ método III O conhecimento do conhecimento. Ali estavam alguns conceitos que, tempos depois, viria a encontrar na ATD, tais como o princípio recorrente e o princípio hologramático (MORIN, 1977, 1986).

O princípio hologramático trata da organização de sistemas e discute a possibilidade de as partes estarem contidas no todo, ao mesmo tempo em que o todo está presente em cada parte. Essa perspectiva afasta-se de esquemas simplificadores e acentua a complexa organização dos sistemas, sejam eles de natureza social, biológica ou antropológica. A Análise Textual Discursiva, no que se refere à construção de categorias, vale-se do princípio hologramático, como percebemos no excerto a seguir:

o sistema é compreendido muito mais pelas relações e interações entre seus componentes de base do que pela natureza destes componentes em si (...) Fragmentar e categorizar não significam permanecer com o foco do trabalho 
apenas nas partes. Pode-se exercitar um movimento dialético entre o todo e as partes, de modo que se consiga ampliar a compreensão do todo, inclusive das interações que o constituem, focalizando temporariamente nas partes e em suas interconexões (p.152-153).

Assim, a defesa da desconstrução de textos do corpus, para buscar a emergência de categorias representativas das novas compreensões, é acompanhada de forte reflexão sobre a vigilância a fim de manter a relação entre o todo e as partes. Como assevera Morin (1986, p. 98), “as partes têm cada uma a sua singularidade, mas nem por isso são puros elementos ou fragmentos do todo, são ao mesmo tempo uns microtodos virtuais."

O princípio recorrente, também denominado recursivo na obra $A$ cabeça bem-feita (2000), igualmente tem sua presença na metodologia de análise estudada, como expresso a seguir:

a análise textual discursiva pode ser compreendida como um processo autoorganizado de compreensão em que novos entendimentos emergem a partir de uma sequência recursiva de três componentes, a unitarização, a categorização e a comunicação de compreensões emergentes (MORAES; GALIAZZI, 2011, p.12).

O princípio da recorrência trata do rompimento com a linearidade de causa e efeito e é definido por Morin (1986, p. 97) como: "processo em que os efeitos ou produtos são ao mesmo tempo causadores e produtores no próprio processo, e onde os estados finais são necessários à geração dos estados iniciais". O excerto sobre ATD apresentado anteriormente faz parte do argumento central do capítulo "Tempestade de luz: a compreensão possibilitada pela Análise Textual Discursiva” (MORAES; GALIAZZI, 2011), e nele percebemos que o princípio recorrente se mostra influenciando o ciclo de análise em diferentes momentos. Entretanto, a recursividade também se inscreve nos diálogos teóricos quando os autores discutem questões sobre argumentos aglutinadores do todo e afirmam ser "este processo por natureza recursivo", ponderando que, para tal, é preciso efetuar "uma crítica permanente dos produtos parciais no sentido de uma explicitação cada vez mais completa e rigorosa de significados construídos e da compreensão atingida" (MORAES; GALIAZZI, 2011, p. 30). Percebemos, ainda, a recursividade sendo discutida na perspectiva de sua importância para a emergência de compreensões renovadas sobre o tema investigado, ideia ilustrada pelo excerto que segue: “a compreensão é produzida a partir de múltiplos movimentos" (p. 31), indicando que, como consequência desses múltiplos movimentos, emergem ideias que retroagem com a ideia global, em um movimento que impulsiona o produto final da interpretação.

As aproximações realizadas até aqui entre princípios da teoria de Morin e da metodologia de Análise Textual Discursiva, dando destaque aos princípios hologramático 
e recorrente, têm a finalidade de chamar atenção para leituras teóricas possíveis no interno da Análise Textual Discursiva. No entanto, a reflexão apresentada não intencionou esgotar a discussão sobre essas possibilidades.

Retornando aos estudos no período de doutoramento, as ideias de Boaventura de Souza Santos foram definitivas para a decisão de trabalhar com pesquisa narrativa. Em seu livro Um discurso sobre as ciências (SANTOS, 1987), o autor dedica alguns parágrafos para tratar da proximidade, no paradigma emergente, entre criação artística e criação científica. Meu orientador, Roque Moraes, utilizava as metáforas para realizar tal aproximação e, ao propor a leitura de Santos, pretendeu desafiar-me a encontrar outro modo de expressar as novas compreensões em minha tese. Tendo como referência principal o livro Narrative Inquiry (2000), de Jean Clandinin e Michael Connelly, a análise seguiu os preceitos dos autores, com formulação de textos de campo, mais descritivos, que originaram os textos de pesquisa, mais interpretativos, apresentados em forma de cartas no relatório final. Entendo hoje que textos interpretativos, com destaque inicial ao argumento central de cada carta, traziam elementos da ATD, como, por exemplo, o esforço de afastamento do campo empírico para exercício de teorização sobre o fenômeno estudado. De lá para cá, assumi a ATD em minha pesquisa e tenho incentivado sua aplicação por meus orientandos.

\section{0 educar pela pesquisa e a escrita como modo de pensar}

Tivemos uma vivência e conversamos muito sobre o educar pela pesquisa naqueles tempos de pesquisa juntos, lembram? Podem apresentar uma síntese de alguma pesquisa realizada que articule a ATD com o educar pela pesquisa?

\section{(Maurivan e Valderez)}

Sim, produzimos juntos artigos nos quais o educar pela pesquisa e a Análise Textual Discursiva configuraram com protagonismo os eixos teórico e metodológico do estudo. Tais artigos, resultantes de pesquisas conjuntas, tratam de temas vinculados à linha de pesquisa à qual nos filiamos, qual seja, Aprendizagem, Ensino e Formação de Professores de Ciências e Matemática. Porém, para mencionar neste texto, escolhemos uma investigação planejada pela necessidade de compreender como os pós-graduandos de nosso Programa de Pós-Graduação em Educação em Ciências e Matemática da PUCRS (PPGEDUCEM) realizavam suas análises e de que forma a ATD entrava nesse 
contexto. Na investigação, contamos com a participação de Rosana Gessinger, colega que atuava no Programa naquele momento. Os dois temas possuem forte presença no PPGEDUCEM/PUCRS desde sua criação, perpassam as linhas de pesquisa do Programa de Pós-Graduação e, na época, eram desenvolvidos pela maioria dos pesquisadores, justificando, assim, a importância do estudo.

A pesquisa foi realizada em 2014, teve como corpus as 55 dissertações defendidas no período 2012-2013 e procurou responder à questão: quais as metodologias de análise escolhidas pelos mestrandos e o que é informado sobre os pressupostos metodológicos por eles assumidos? O estudo utilizou Análise Textual Discursiva (ATD) como metodologia de análise, e, por emergência, chegamos a duas categorias: (1) destaque a elementos inerentes ao processo de ATD e (2) moderada referência aos princípios da ATD.

Identificamos que a maioria dos estudos (43 dissertações) empregou a ATD em suas análises e que os acadêmicos, nos capítulos metodológicos elaborados, nomeavam como elementos importantes, na perspectiva teórica da Análise Textual Discursiva, aqueles relacionados com o processo ou operacionalização. Porém, outros elementos também importantes emergiram, mas com menor intensidade. Entre eles, elementos associados aos princípios da ATD, como auto-organização, impregnação e emergência, bem como os associados à finalização do processo, que inclui a produção de metatexto, escrita e teorização. A baixa referência aos conceitos mencionados encaminha ao entendimento de que eles ainda são pouco compreendidos na prática da ATD. Finalizamos o texto com a seguinte reflexão:

\begin{abstract}
Atribui-se esse desequilíbrio à inexperiência dos mestrandos com cenários de pesquisa, tendo em vista que os estudantes do referido programa são professores da Educação Básica na rede pública ou privada, onde processos investigativos são incipientes em sua rotina profissional. Para a maioria, o curso de Mestrado representa o primeiro contato com investigações, especialmente as de cunho qualitativo, comuns na área da Educação (RAMOS; LIMA; GESSINGER, 2016, p. 137).
\end{abstract}

Dos mestrandos que fizeram parte do estudo apresentado, muitos deles retornaram para realizar estudos de doutoramento; dentre eles, alguns se dedicaram a aprofundar suas compreensões sobre a Análise Textual Discursiva, se tornaram nossos parceiros de pesquisa e atualmente disseminam a metodologia em questão em outros espaços acadêmicos, em diferentes estados do Brasil. 
Essa foi uma das experiências em que escrevemos juntos, mas houve tantas outras em que a escrita, o educar pela pesquisa e a Análise Textual Discursiva permearam nossas ações na pesquisa, não?

\section{(Maria do Carmo)}

Sim, a temática de minha tese foi o educar pela pesquisa. Recém havia sido publicado o livro Educar pela pesquisa: princípio científico e educativo (DEMO, 1996), que foi amplamente discutido no grupo de pesquisa.

Retomando o livro oriundo de minha tese (GALIAZZI, 2003), percebo que apenas consegui compreender na tese de meu orientador aspectos referentes às Licenciaturas e seus dilemas, mas sua guinada de visão de mundo a partir de seu encontro com a Fenomenologia não me chamou a atenção. Diria que o fenômeno da Fenomenologia não se mostrou para mim naquele momento (GIORGI, 1994). O que na época se evidenciou muito importante foi o encontro com o livro Escrever é preciso: o princípio da pesquisa, de Mário Osório Marques (1997). Dele, extraio alguns fragmentos em que se apresentava a escrita como modo de pensar.

Ao ler que uma pesquisa começa pela escrita, fui desafiada a aderir à ideia de ir colocando o pensamento na folha em branco. A partir daí, construí aos poucos um caminho de pesquisa. Nesse desafio, encontrei parceiros de trabalho em interlocutores teóricos e empíricos.

Como afirma o autor recém citado, o maior desafio de escrever é o ato inaugural. Depois, à medida que se escreve, vão se estruturando os pensamentos, e os assuntos surgem, assim como os temas a serem aprofundados. Assumi que é pelo ato de escrever que a pesquisa precisa iniciar, sem que haja perda de tempo. A partir do exercício da escrita, desenrola-se toda a pesquisa, e chega um momento em que a pesquisa adquire vida própria e ela própria determina seu caminho.

Como está afirmado:

Não poderá o pesquisador estranhar quando, em dado momento, estiver metido na conversa alguém de cuja existência sequer suspeitara. $\mathrm{O}$ tema o convidou, e o tema o comanda. $\mathrm{O}$ aspecto criativo e a originalidade da pesquisa estão justamente nisso de ouvir o que não se perguntou, até mesmo de quem não se conhecia (MARQUES, 1997, p. 99).

Foi o começo de um caminho por terras a explorar. No início, busquei como aliados alguns leitores que permaneceram comigo ao longo da pesquisa, com olhar quieto, 
sempre à espreita, tentando enxergar com mais nitidez as sombras de meu pensamento contidas no escrever.

Busquei-me como primeira leitora, sabendo que iria escrever, ler, reler e reescrever aquele texto muitas vezes. Tive outros aliados importantes de mais tempo nessas andanças de aprender a pesquisar em Educação, além de meu orientador e de meu coorientador, ambos pioneiros nas discussões sobre formação de professores de Ciências no Rio Grande do Sul. A escrita, a leitura, o diálogo, o modo de pensar com o outro também foram aprendidos e muito exercitados nos projetos de formação de professores de Ciências, especialmente no doutorado, com grupos de leitura e escrita.

Penso que essa ideia da escrita recursiva ficou fortalecida em minha prática de professora e de pesquisadora no encontro com a Fenomenologia e com a Hermenêutica Filosófica, mas outro aspecto de minha tese alinhava compromissos metodológicos como processos cíclicos de pesquisa.

Assumi a pesquisa qualitativa, pois não poderia ser outro o paradigma de minha pesquisa de doutorado. Isso porque, naquela pesquisa, procurei compreender a sala de aula de professores que faziam pesquisa sobre/ em sua sala de aula. A sala de aula é um sistema complexo e está embebida de subjetividade, ideologia, dimensões valorativas. Cada sala de aula é uma realidade dinâmica que a diferencia de qualquer outra no tempo e no espaço.

A análise de dados seguiu os procedimentos da Análise de Conteúdo, como os propostos por Moraes (1994) e Ramos (1999). A leitura das informações produzidas é uma das características fundamentais nesse tipo de procedimento analítico, a fim de o pesquisador impregnar-se do texto para chegar a interpretações articuladas fortemente a argumentos teóricos. A análise consistiu na decomposição das falas em unidades de significado $^{6}$, que, em uma síntese posterior, foram novamente agrupadas em função de semelhanças de sentido. Cheguei à categorização e delas à possibilidade de descrição por meio da elaboração de textos, e foram esses textos que possibilitaram uma interpretação do conjunto de análises realizadas.

Nessa pesquisa, o corpus de análise foi se constituindo a cada entrevista realizada, a cada novo diálogo estabelecido, em um processo de pesquisa dialética. Planejei

\footnotetext{
${ }^{6}$ Em Moraes (1999), as expressões unidades de análise, unidades de registro e unidades de significado são tratadas como sinônimos. No livro Análise Textual Discursiva (MORAES; GALIAZZI, 2007), o mesmo ocorre com unidades de análise e unidades de significado ou sentido.
} 
diferentes ciclos interconectados, que estenderam uma rede sobre o fenômeno em estudo (REASON; ROWAN, 1981).

Acredito ter realizado ciclos múltiplos de pesquisa, cada um deles caracterizado pelo questionamento, pela construção de argumentos cada vez mais pertinentes, advindos da releitura e análise persistentes das informações obtidas nas entrevistas, da leitura de teóricos e da comunicação. Esses ciclos foram concretizados por meio da escrita e reescrita dos textos de análise e do relatório de pesquisa, em um exercício de elaboração de um relato que mostrava minha compreensão do fenômeno estudado.

Estava na Análise de Conteúdo, mas tinha encontrado o escrever como modo de pensar. Essa ideia da escrita como artefato cultural epistêmico, trazia especialmente de meu encontro com Gordon Wells $(1999,2001)$ e de autores da abordagem sociocultural, como Wertsch, Del Río e Alvarez (1998). O encontro com esses teóricos também sinaliza o contexto de atenção à contribuição de Lev Vygotsky nesses autores, muito presentes nas discussões teóricas nos programas brasileiros de pesquisa em Educação. Esse conjunto de modos de pensar estava presente na forma de pensar do grupo de pesquisa.

\section{(Valderez)}

Dando continuidade à reflexão de Maria do Carmo, reafirmo a forte presença de solicitação de escrita em nossos grupos de estudos e de pesquisa, enfatizando que a atividade oportunizava a comunicação dos conhecimentos em construção, além da reflexão crítica e coletiva sobre as ideias apresentadas. O propósito era, em um movimento dialógico, problematizar as ideias explicitadas, com a intenção de torná-las mais complexas, enriquecendo-as com nuances não expressas até aquele momento.

O exercício de escrever incorporou-se fortemente ao meu fazer de professora e de pesquisadora. Trazendo o tema da escrita para o contexto deste artigo, entendo ser a escrita marcante no uso da ATD e que escrever cumpre vários papéis essenciais na realização da análise. Atua como dispositivo que favorece ao analista a construção de um número cada vez maior de sentidos a partir do corpus. A multiplicidade de sentidos emergentes, expressos pela escrita, aliada à compreensão da interdependência entre as várias ideias, vai constituindo um conjunto denso, pleno de possibilidades para a ocorrência da auto-organização, a qual pode dar origem a outra ordem pelo estabelecimento de relações até então não pensadas, encaminhando, assim, para novas compreensões do fenômeno investigado. É a escrita como mecanismo para compreender. 
O processo de escrita desempenha, ainda, papel fundamental na argumentação. Em minha trajetória formativa, a compreensão dessa operação discursiva deveu-se, principalmente, a leituras de teóricos, como Perelman e Tyteca (1996) e Gustavo Bernardo (2000), aos quais, hoje, ainda acrescentaria Simon, Erduran e Osborne (2007) e Ortega, Alzate e Bargalló (2015).

$\mathrm{Na}$ ATD, é por meio da escrita que se adensam os argumentos sobre as novas compreensões efetuadas, em um movimento interativo de reconstrução das ideias do corpus. É na escrita de textos intermediários e finais que o autor tem condições de, por exemplo, situar o fenômeno sob investigação em seus contextos mais próximos, como sala de aula, escola e comunidade escolar, e mais distantes, incorporando os elementos culturais, sociais, políticos e históricos; expor as inter-relações efetuadas entre os sentidos em discussão; colocar em diálogo as múltiplas vozes advindas dos campos empírico e teórico. A argumentação tecida movimenta-se no sentido da construção de respostas plausíveis, verossímeis, à questão inicialmente formulada, isto é, o que está sendo dito é uma resposta possível, sem estatuto de verdade, sem ser considerada a única resposta possível. É a escrita como mecanismo de comunicação.

Com a última ideia, incluo na pauta desta reflexão a presença do autor nos textos escritos. A escrita argumentativa na ATD encoraja o pesquisador a ocupar seu lugar de autor dos textos produzidos, pois é ele quem ata os fios dos discursos e é ele quem atribui sentidos ao multifacetado conjunto de ideias - incomuns, contraditórias, díspares ou convergentes -, engendrando resposta e proposições com perspectivas inéditas. A questão da autoria foi estudada por mim especialmente em Bakhtin (1992, 1997), com inspiração, também, em Roland Barthes (1988). É o escrever para tornar-se autor.

Escrever para compreender, escrever para comunicar, escrever para tornar-se autor. Quando esse movimento é realizado de forma coletiva, alcançam-se, no percurso, entendimentos muito profundos, como se discute a seguir.

\section{(Maurivan)}

Eu só desejo acrescentar que, no grupo de pesquisa, também era muito intensa a participação de todos, lendo e comentando as produções escritas dos colegas. O Roque insistia na escrita, mas estimulava o diálogo sobre os textos produzidos, processo fundamental além da comunicação, passando à validação pelos participantes de suas apropriações, de suas verdades, mesmo que transitórias. Era a possibilidade de apresentarmos os escritos que nos fazia sentir estimulados a escrever mais e com mais 
consistência. Tomávamos a consciência do que tínhamos escrito pela crítica dos colegas e pela autocrítica. Isso mostra a importância do grupo no processo da escrita e da análise.

\section{A escrita no coletivo como modo epistêmico de pesquisa}

De que modo a escrita coletiva teve influência na compreensão da ATD?

\section{(Maria do Carmo)}

Não lembro bem se foi ao final de meu doutorado que veio o convite de nosso orientador para formar um grupo de estudos para compreender mais a Análise de Conteúdo e a Análise de Discurso, em parceria com Maurivan, Valderez e eu, parceria desde lá que se expressa também neste dossiê. A cada semana, alguém apresentava alguma discussão sobre uma das duas abordagens. Lembro-me da apresentação da Análise de Discurso de Michel Foucault, de discussões sobre teorias implícitas e sobre Análise de Conteúdo (MORAES, 1999). O texto mostra alguns elementos que me parecem evidenciar um movimento na Análise de Conteúdo, embora algumas palavras remetessem a um entendimento vindo da tradição da Análise de Conteúdo quantitativa.

O primeiro movimento claro é a definição que, de técnica, passa a ser metodologia de análise de dados em um paradigma qualitativo, no entanto, é mantida a ideia de descrição sistemática, qualitativa ou quantitativa. Recentemente, Bello (2018) aponta que a discussão entre quantitativo e qualitativo é antiga, desde os gregos, mas que foi com a ciência física instaurada por Galileu que ficou mais marcada a distinção, acentuada mais fortemente pelo Positivismo.

No texto de Moraes (1999), a Análise de Conteúdo avançava de processos indutivos e intuitivos para atingir níveis de compreensão dos fenômenos a investigar, e um texto pode ter diferentes sentidos. Estava presente, entretanto, a possibilidade de interpretar o sentido que o emissor deu à mensagem, o que ele quis dizer naquele texto. Esse aspecto, a partir de minha compreensão da Hermenêutica Filosófica que se atém ao texto, não tem como ser alcançado (GADAMER, 1997).

Considerando o texto anterior (MORAES, 1994), a ideia de categoria a priori e emergente mantém-se nesse texto, e são apresentados os procedimentos: 1 - Preparação das informações; 2 - Unitarização ou transformação do conteúdo em unidades; 3 Categorização ou classificação das unidades em categorias; 4 - Descrição; 5 Interpretação. E aqui estão palavras que permanecem na ATD (2006), como unitarização, 
unidades de sentido, unidades de significado, unidades de análise e unidades de contexto. Esta última unidade, de modo geral, é mais ampla do que a de análise, que serve de referência àquela, fixando limites contextuais para interpretá-la. Também se mantém, ao menos nos primeiros textos da ATD, a separação enfatizada nessas duas formas de elaboração das categorias. Na medida em que assumo que o fenômeno se mostra ao pesquisador, enfraquece minha aproximação, que nunca foi muito próxima, com as categorias a priori.

Voltando ao texto (MORAES, 1999), lá estava a indicação para iniciar o processo de análise logo que houvesse alguma unidade de contexto, com esforço para a categorização em processos recursivos. As categorias, argumentava o autor, representavam o resultado de um esforço de síntese de uma comunicação, destacando-se nesse processo seus aspectos mais importantes. Também o retorno periódico, o refinamento das categorias e a descrição foram enfatizados. Contudo, se a descrição era importante na Análise de Conteúdo, não era suficiente, sendo necessário chegar à interpretação. Nesse texto, o autor problematizou o termo inferir, mais próximo de pesquisas quantitativas, elemento que não havia sido problematizado no texto anterior.

Se essas são marcas da Análise de Conteúdo, consultando Moraes (1991, 2019), encontrei as mesmas palavras - unidades de significado intermediárias, iniciais e globais - a partir da perspectiva fenomenológica em Giorgi (2014), em que o método na investigação fenomenológica não era uma ordenação de etapas. O método é um caminho a ser trilhado em que nada é predeterminado. Os procedimentos de análise incluíam ler intensamente o material para captar o sentido do todo, voltar ao material e separar o todo em unidades, reescrevê-las e realizar a síntese.

O método fenomenológico apresentado por Giorgi (1985) foi descrito brevemente em Moraes (1991, 2019) e em Metzler, Carpena e Borges (1994), consistindo nas etapas: a) fazer a leitura de cada texto, captando o sentido; b) discriminar as unidades de significado; c) delinear e reescrever as unidades em função do fenômeno em estudo; d) realizar a síntese das unidades em uma perspectiva consistente.

Sobre o método, Giorgi (2014) registra que, embora possa parecer que a primeira etapa seja óbvia, ela precisa ser salientada. Com relação às unidades de significado, ele ressalta que, cada vez que percebe uma mudança de sentido, o pesquisador deixa isso assinalado. A atitude do pesquisador deve ser aberta para o encontro de significados imprevisíveis. As unidades de significado não existem prontas, mas são reelaboradas pelo pesquisador, que as deixa em linguagem condizente com o fenômeno analisado. 
Terminados um ou dois semestres de estudo no grupo de estudos, o Prof. Roque apresentou um conjunto de textos de sua autoria sobre a compreensão oriunda das nossas discussões semanais e sugeriu ao grupo a leitura desses textos, uma leitura crítica para contribuir com sua reescrita. Fiz com afinco essa revisão. Costumo dizer que fiz palavra por palavra, usando o revisor do Word, e o texto avermelhou de tal modo que Roque me convidou para ser coautora no livro.

Durante as discussões do grupo, afirmávamos ser muito diferente da Análise de Conteúdo o apresentado por Roque nos textos discutidos, e o nome estava em aberto, aparecendo, em alguns de seus escritos, Análise Textual, Análise Textual Qualitativa e, por último, ATD. No texto “Tempestade de Luz" (MORAES, 2003), a dúvida do título transparece. No título, está ATD; no interior do texto, Análise Textual Qualitativa.

Algumas afirmativas são importantes nesse texto. A afirmativa de que não se pretende testar hipótese vai mostrar, logo no início, uma intenção mais compreensiva do que explicativa ou generalizante, também uma aproximação fenomenológica (GIORGI, 2014).

Outra ideia que foi trazida para a ATD foi a de auto-organização, e outras palavras foram colocadas ao lado de unitarização, como desmontagem, de categorização, como estabelecimento de relações e captação do novo emergente, como está no texto:

\footnotetext{
Pretende-se defender o argumento de que a ATD pode ser compreendida como um processo auto-organizado de construção de compreensão em que novos entendimentos emergem a partir de uma sequência recursiva de três componentes: a desconstrução dos textos do "corpus", a unitarização; o estabelecimento de relações entre os elementos unitários, a categorização; o captar o emergente em que a nova compreensão é comunicada e validada. Esse processo em seu todo é comparado a uma tempestade de luz. Consiste em criar as condições de formação dessa tempestade em que, emergindo do meio caótico e desordenado, formam-se "flashes" fugazes de raios de luz sobre os fenômenos investigados, que, por meio de um esforço de comunicação intenso, possibilitam expressar novas compreensões atingidas ao longo da análise. Nesse processo a escrita desempenha duas funções complementares: de participação na produção das novas compreensões e de sua comunicação cada vez mais válida e consistente (MORAES, 2003, p. 192).
}

Outro ponto que se mostra nesse texto é a dificuldade de atribuir sentidos objetivos aos textos, pois os significados são e podem ser sempre outros, embora nem todos sejam possíveis. Manteve-se no texto a diferenciação entre manifesto e implícito, apontada em Olabuenaga e Ispizúa (1989), autores da Análise de Conteúdo, e a atitude fenomenológica é buscada apostando-se que a leitura dos textos fosse feita com a intenção de o Outro se mostrar. Estava presente a autoria do pesquisador, pois cada processo de análise é dito 
como único, e o processo a cada pesquisa precisa ser reinventado, como colocado nos textos de Análise de Conteúdo (MORAES, 1994, 1999).

Considerando a compreensão apresentada anteriormente, de uma atitude fenomenológica como transformadora de uma visão de mundo (MORAES, 1991), o primeiro momento é o da desordem:

\begin{abstract}
A luz de uma tempestade só é possibilitada pela formação de um sistema conturbado de nuvens em permanente agitação e movimento. A desordem é condição para a formação de novas ordens. Novas compreensões dos fenômenos investigados são possibilitadas por uma desorganização dos materiais de análise, possibilitando ao mesmo tempo uma impregnação intensa com os fenômenos investigados (MORAES, 2003, p. 196).
\end{abstract}

É outro o modo de expressar os procedimentos em que as metáforas vão estar presentes em todos os textos (MORAES; GALIAZZI, 2006; 2016). A presença da metáfora atribuindo valor cognitivo e interpretativo agrega valor epistemológico na ATD. A metáfora, antes considerada um ornamento linguístico que não poderia estar presente no discurso científico - que precisa ser claro, preciso e determinado -, passa a ter o status de uma operação cognitiva fundamental. A metáfora une razão e imaginação (LAKOFF; JOHNSON, 2002), e entendo que sinalize para esse modo de pensar que percebíamos nos textos analisados no grupo que diferenciavam a Análise de Conteúdo da ATD.

Com relação à categorização, que é a aproximação por sentidos, exige um retorno cíclico, elemento presente da hermenêutica. Mantém ainda a estrutura de categorias em hierarquia de subcategorias a categorias finais, de maneira semelhante à apresentada por Bicudo (2011) em sua descrição da metodologia qualitativa em uma abordagem fenomenológica.

O sistema de categorias hierarquizadas em categorias iniciais, subcategorias ou categorias intermediárias e categorias finais foi foco de análise em Sousa e Galiazzi (2017a, 2017b). O argumento foi de que a ATD, que segue um conjunto linear de etapas e produz um sistema hierarquizado de categorias, pode, durante a análise, ser reorganizada e de que as informações podem ser focadas não em um sistema hierarquizado, mas em rede, como mostrado em Bicudo (2000, 2011).

Na ATD, com relação à categorização, diferencia as categorias a priori mais próximas da Análise de Conteúdo, citando Bardin (1977), das categorias emergentes com aportes do paradigma naturalístico, mas é em uma aproximação com a Fenomenologia que aparece a intuição: 
Entendemos que se pode descrever ainda um terceiro método de produção de categorias. É o método intuitivo. Chegar a um conjunto de categorias por meio da intuição exige integrar-se num processo de auto-organização em que, a partir de um conjunto complexo de elementos de partida, emerge uma nova ordem. O processo intuitivo pretende superar a racionalidade linear que está implícita tanto no método dedutivo quanto no indutivo. Pretende que as categorias tenham sentido a partir do fenômeno focalizado como um todo. As categorias produzidas por intuição originam-se a partir de inspirações repentinas, "insights" que se apresentam ao pesquisador a partir de uma intensa impregnação nos dados relacionados aos fenômenos. Representam aprendizagens auto-organizadas que são possibilitadas ao pesquisador a partir de seu envolvimento intenso com o fenômeno que investiga (MORAES; GALIAZZI, 2007, p. 24).

Lembro-me sempre da referência à metáfora da clareira, de Heidegger, com a alusão à verdade, que Roque abordava ao apresentar a metáfora da tempestade de luz! Ou seja, a partir desse texto, começa um distanciamento ainda maior dos argumentos da Análise de Conteúdo, o que se percebe também na conclusão do texto, em que as metáforas da tempestade e da luz são reunidas, e a aposta está em um processo autoorganizado. E assim se instaura a ATD transformada em livro (MORAES; GALIAZZI, 2007), com aproximações e distanciamentos da Análise de Conteúdo, sem início, mas tendo história.

Após o doutorado, fui convidada a trabalhar no Programa de Pós-graduação em Educação Ambiental (PPGEA) da FURG, na disciplina de Metodologia de Pesquisa, em parceria com Dr. José Vicente de Freitas e posteriormente com a Dra. Elisabeth Schmidt, e com colaboração do Prof. Roque Moraes, que veio a ser professor sênior da FURG após sua aposentadoria na PUCRS até 2011. Dessa experiência, pensando na compreensão da importância da escrita como artefato cultural que transforma o sujeito que escreve, organizamos os Seminários de Metodologia de Pesquisa Qualitativa, realizados de 2001 a 2011, em que os alunos de pós-graduação escreviam projetos de pesquisa em três versões consecutivas durante a disciplina de Metodologia de Pesquisa. Ao final, inscreviam-se no Seminário de Pesquisa e em rodas de conversa (WARSCHAUER, 2001) e apresentavam seus projetos de pesquisa a colegas e professores.

\section{(Maurivan e Maria do Carmo)}

A escrita no coletivo concretizou-se mais uma vez em um artigo, no qual relatamos a experiência coletiva de escrita realizada em uma disciplina de ATD (GALIAZZI; RAMOS, 2013). Nesse artigo, mostramos um exercício de Análise Textual Discursiva em uma disciplina de um programa de pós-graduação, apoiada por um ambiente virtual. A intencionalidade da pesquisa foi a compreensão dos participantes 
sobre o processo de aprender. Ao apropriar-se da metodologia de análise, o grupo reconstruía seus saberes sobre o aprender. A esse grupo, demos o nome de Comunidade dos Aprendentes do Aprender, assim caracterizada no ambiente virtual:

\begin{abstract}
O grupo "Aprendentes do Aprender" é uma comunidade aprendente formada de professores e alunos de pós-graduação interessados em repensarem e reconstruírem suas compreensões sobre o aprender nos contextos em que atuam. Todos se voltam a produções escritas como resultado de pesquisas individuais e coletivas realizadas a partir da interação dentro da comunidade e para além dela, confrontando compreensões e procurando reconstruir as próprias teorias e entendimentos na confrontação com outros pontos de vista, seja de sujeitos empíricos, seja de sujeitos teóricos com os quais a comunidade aprendente pretende interagir. Todos os materiais da pesquisa ficarão disponibilizados no grupo virtual. As produções finais, em forma de textosartigos, serão lidas por todos os participantes e criticadas para fins de qualificação (GALIAZZI; RAMOS, 2013, p. 870).
\end{abstract}

A ideia de escrever em diálogo com o outro era mostrada pelo Prof. Roque a partir da leitura de "Ressurgir de Fênix", um dos textos do livro de ATD:

O diálogo com um texto, de modo especial quando o texto é do próprio
dialogante, sempre me lembra algumas referências a partir das quais se origina
esta ideia de dialogar com textos. Um dos autores que lembro, um dos
principais gurus que têm desafiado nossos entendimentos e reconstruções,
aponta para a importância de professores produzirem seus próprios textos em
suas disciplinas e de colocá-los à leitura e crítica dos alunos. Mas nisso é
importante desafiar os alunos à contraleitura, não leitura receptiva e bíblica
(conforme crítica de Bernardo Gustavo (2000), ou então sugestão de Smith
(1999) de ler como autor, sabendo o que está procurando...). O processo
descrito mostra-se como um modo adequado para o desenvolvimento em
pesquisa qualitativa e como ação para a reconstrução do conhecimento sobre
algum tema em uma comunidade aprendente (GALIAZZI; RAMOS, 2013, p.
871).

Assumir-se como autor de um texto exige reconstrução dos próprios conhecimentos e teorias. A metáfora da ave que ressurge depois de ter sido queimada pelo fogo indica que o conhecimento precisa ser desconstruído. É o envolvimento com o tema, a partir de um envolvimento intenso, que produz o texto final, considerando os exercícios de síntese na categorização e o diálogo com os teóricos e com a realidade empírica. A intenção é alcançar compreensão ampliada que leve a elaborar argumentos validados pela comunidade de especialistas. No processo de reconstrução coletiva dos discursos sociais, há o compromisso político de potência de transformação da realidade e do modo de existência do ser humano.

Ao final da disciplina, concluímos que, com o exercício de ATD, compreendemos melhor o que se mostrou sobre o aprender naquela comunidade aprendente. $\mathrm{O}$ ambiente virtual foi importante como lugar de acesso às atividades de todos. Para os participantes, o tema, a partir do conhecimento expresso no início, por meio da análise, foi se tornando 
mais complexo. O processo de ensinar ATD mediante um tema mostrou-se adequado, tanto para a apropriação da metodologia quanto para a reconstrução do tema em foco.

\section{$5 \mathrm{O}$ encontro com a Fenomenologia e com a Hermenêutica Filosófica}

\section{(Maria do Carmo)}

A Fenomenologia representou uma visão distinta sobre fazer ciência para o Roque. Como ele afirma, o encontro com a Fenomenologia foi o despertar de uma nova visão. O que se destaca desse encontro?

Meu encontro com a Fenomenologia tem sido processual a partir de dois momentos: a) pelo encontro com Bicudo (2011) e pelo encontro com a tese de Roque Moraes, que li atentamente para a transformação da tese (MORAES, 1991). Essas duas leituras fizeram-me retomar o livro de ATD (2007) e buscar elementos que associei à Fenomenologia. Nesse retorno, encontrei-me também com a Hermenêutica Filosófica.

Para Giorgi (2014), que delineou o método fenomenológico de pesquisa na Psicologia citada em Moraes (1991, 2019), algumas ideias e palavras sinalizam um estilo de pensamento fenomenológico. Fenomenologia é o estudo sistemático do que se apresenta à consciência e leva muito a sério o papel desta. A consciência mostra-nos objetos, e a esse mostrar-se Husserl deu o nome de intuição. Há muitas discussões teóricas sobre esse conceito na Fenomenologia, mas não o abordarei neste texto.

No contexto fenomenológico, também a palavra existência tem um sentido próprio, referindo-se às presenças que se mostram da realidade. Isso leva a pensarmos no sentido atribuído ao fenômeno; "a presença daquilo mesmo que é dado" (Idem, p. 389). "O fenômeno como o que se manifesta em seus modos de aparecer, olhando-o em sua totalidade de maneira direta, sem a intervenção de conceitos prévios que o definam e sem basear-se em um quadro teórico prévio que enquadre as explicações sobre o visto" (MARTINS; BICUDO, 2006, p. 16).

Outra palavra que se mostra no estilo de pensamento fenomenológico é intencionalidade. Significa que a consciência sempre é dirigida a um objeto; assim, a dicotomia sujeito e objeto é transposta, pois sujeito e objeto estão ligados - podem ser distinguidos, mas não separados.

Em Galiazzi e Sousa (2020), a partir da intencionalidade, busca-se inicialmente descrever os sentidos dados à palavra fenômeno, e a essa descrição articulam-se dois movimentos analíticos, descendente e ascendente. Conclui-se que, na ATD, fenômeno se 
associa com intuição, desorganização, nova organização auto-organizada, que leva a novas compreensões mediadas pelo escrever, em um movimento entre perspectivas fenomenológicas e hermenêuticas que permitem a fusão de seus horizontes para se chegar à expressão escrita do compreendido.

Destaco as palavras intencionalidade e intuição, que indicam um estilo de pensamento fenomenológico (GIORGI, 2014). No encontro com a Fenomenologia, Giorgi (2014) ainda afirma que não há pesquisa fenomenológica sem a redução, como apontado anteriormente com o exposto sobre teorias de aprendizagem.

Nesse sentido, Neves (1999) impactou-me com a associação da redução fenomenológica ao touro de Picasso ao abordar o que é ciência. Mais ainda, impactoume o fato de eu, em apresentação da ATD, mostrar essa associação e o autor estar presente sem que eu o conhecesse pessoalmente. Trago a imagem a seguir (Figura 1), que, a meu ver, mostra o sentido fenomenológico da redução como apontado em Neves (2008).

Figura 1: A metamorfose de um touro e a redução fenomenológica

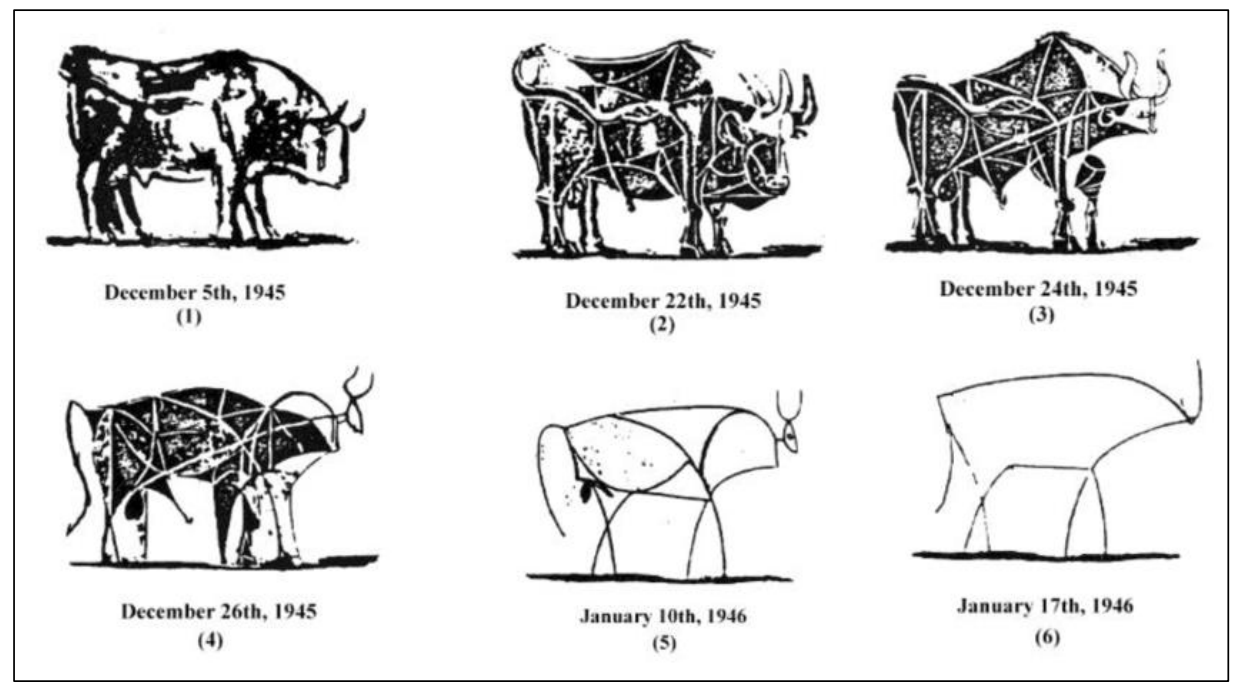

Fonte: (NEVES, 1999, p. 110)

A descrição é outro procedimento presente no método fenomenológico. Para Giorgi (2014), trata-se de "atribuir palavras ao objeto intencionalmente estudado, exatamente como ele aparece. Descrever limita-se ao dado e a uma descrição concreta e detalhada do objeto e isto já comporta uma interpretação" (GIORGI, 2014, p. 395).

Compreender a descrição apresentou-se como uma intencionalidade na compreensão da ATD (2007) a partir de Sousa e Galiazzi (2017a), o que levou à conclusão de que, na ATD, a descrição se mostra nos metatextos na presença de informações dos interlocutores empíricos da pesquisa e se diferencia das proposições de 
descrição apresentada pela Análise de Conteúdo, que se estabelece mais por informações quantitativas, inferências, frequências e estatísticas. Não se atém a todos os quesitos exigidos em uma descrição densa. Insere-se na descrição fenomenológica com os interlocutores empíricos muito presentes no metatexto, em um movimento de escuta, à espera de que o fenômeno se mostre. A descrição, embora importante em uma análise, não basta. Ela exige movimento de interpretação para ampliar a compreensão.

Assim, considerando o apresentado por Bicudo (2011) sobre o enxerto hermenêutico, a partir da descrição de cunho fenomenológico, na ATD a hermenêutica sempre foi o modo presente de interpretação, que pode ser realizado em dois movimentos analíticos propostos por Gadamer (2000): da palavra ao conceito e, depois, um retorno do conceito à palavra, em movimentos descendentes e ascendentes (ROHDEN, 2012).

Foi nesse modo intencional de compreender que também se expressou o sentido de compreensão na ATD a partir da imersão na Hermenêutica Filosófica (GADAMER, 2006).

\begin{abstract}
Neste estudo, compreendeu-se mais acerca do uso da metodologia de ATD, que consiste no encontro com o fenômeno a ser investigado, que não se mostra de imediato, mas que se elucida com o movimento da análise. Entendeu-se que a análise com a ATD possibilita colocar-se em um jogo entre as perspectivas epistemológicas que se carrega, as teorias a priori e as emergências teóricas possibilitadas pelo movimento interpretativo hermenêutico. Nesse caminho, o exercício feito a partir dos significados das palavras intencionalmente escolhidas, permite movimentar-se baseado em preconceitos com vistas a horizontes de compreensão que podem ser ampliados. Nesse processo analítico, pensando no diálogo sobre ATD, é que existe a possibilidade de intensidade, de atentar para a importância da descrição fenomenológica em um movimento de escuta ao que se mostra na interlocução empírica para o exercício hermenêutico de atenção às palavras do pesquisador, para que as précompreensões se estendam a compreensões ampliadas (SOUSA; GALIAZZI, 2018, p. 813).
\end{abstract}

Todavia, não posso deixar de abordar minha imersão na Hermenêutica Filosófica sem citar Nadja Hermann. No IX Seminário de Metodologia de Pesquisas Qualitativas, organizado com colegas, e Roque Moraes estava comigo nessa organização, Nadja Hermann participou de uma mesa-redonda em que apresentou a Hermenêutica Filosófica e a importância do círculo hermenêutico (HERMANN, 2010; GRONDIN, 1999).

A compreensão de círculo hermenêutico a partir de Hermann (2010) leva-me a Moraes (1991; 2019), em que o retorno sistemático aos fenômenos para maior aprofundamento da compreensão constitui o círculo hermenêutico. Como afirma o autor, "o círculo hermenêutico propicia o desvelamento gradual e progressivo de novas camadas veladas, conduzindo a uma compreensão cada vez mais aprofundada do fenômeno" (idem, p. 28). 
Gadamer (2006, p. 331) remete a Heidegger a retomada do círculo hermenêutico como positivo e elevado a conceito:

O conceito de círculo hermenêutico significa que no âmbito da compreensão não se pretende deduzir uma coisa de outra de modo que o erro lógico da circularidade na demonstração não é aqui nenhum defeito do procedimento, mas representa a descrição adequada da estrutura do compreender.

Grondin (2012), ao apresentar uma síntese da Hermenêutica, mostra seus movimentos históricos, trazendo a perspectiva metodológica de análise de textos em Dilthey, sua superação em Heidegger e o distanciamento de textos para a hermenêutica da existência com o retorno aos textos por Rudolf Bultmann, para quem o entendimento de texto é para o que se mostra do texto, e não para a psicologia do autor. Foi também Bultmann o primeiro autor a aplicar o círculo hermenêutico na concepção de Heidegger, antecipando, assim, a concepção de Hans-Georg Gadamer de hermenêutica como aplicação e de Paul Ricoeur o entendimento como abertura a um mundo (GRONDIN, 2012). Moraes buscou a metáfora em Ricoeur (2000) para compreender a metáfora na ATD. Ao trazer esses autores, quero destacar a importância da historicidade que a abordagem hermenêutica pode trazer à ATD.

Nesse sentido, penso que a ideia de fusão de horizontes trazida no título deste texto, com inspiração em Gadamer (2004, p. 311), quando afirma que "compreender é sempre o processo de fusão de horizontes presumivelmente dados por si mesmos", pode ser um elemento que se mostrou potente para agregar na ATD.

\section{A fusão de horizontes para um reinício}

Neste texto, procuramos mostrar os caminhos de elaboração da ATD a partir dos percursos, de registros, de lembranças que Roque deixou registrados em suas publicações e em nós.

Marcamos a presença inicial da Análise de Conteúdo com uma nova visão a partir da Fenomenologia de Husserl, com imersão em outras compreensões, como a Hermenêutica e a Complexidade.

No processo de escrever este texto, percebemos mais ainda que sempre foram características de nosso orientador a preocupação com seus alunos e o esmero e humildade em ensinar. Ser professor era seu modo de ser, e essa característica está muito presente na elaboração da ATD em sua perspectiva ontológica de transformação do pesquisador. 
Se nos propusemos neste texto a compreender mais sobre a ATD, outros tantos elementos presentes suscitam outros textos e estudos. Que este texto tenha sido um convite!

Encerrando o círculo hermenêutico percorrido por ora, lembrando a influência da Fenomenologia, da Complexidade e da Hermenêutica no pensamento de nosso orientador e espelhando-nos no que provocou a presença de Joel Martins, marcada por Bicudo e Espósito (1997), que escrevem a partir das aulas interrompidas do Mestre, como chamaram Joel Martins, pensamos que este texto também é uma homenagem a Roque Moraes, nosso Mestre. Aqui, fomos mostrando como nos tornamos professores e pesquisadores pela presença inesquecível de sua vivacidade intelectual, seu compromisso com o outro na produção coletiva da compreensão da pesquisa, que teve sempre um foco: a formação de professores.

\section{Referências}

BAKHTIN, M. Estética da criação verbal. São Paulo: Martins Fontes, 1992.

BAKHTIN, M. Problemas da Poética de Dostoiévski. Rio de Janeiro: Forense Universitária, 1997.

BARDIN, L. Análise de conteúdo. Lisboa: Edições 70, 1977.

BARTHES, R. O rumor da língua. São Paulo: Brasiliense, 1988.

BELLO, A. A. Qualidade ou quantidade: um desafio pela nossa época. In: SEMINÁRIO INTERNACIONAL DE PESQUISA E ESTUDOS QUALITATIVOS, 5., 2018, Foz de Iguaçu. Anais... Foz do Iguaçu: SE\&PQ, 2018. s.p.

BERNARDO, G. Educação pelo argumento. Rio de Janeiro: Rocco, 2000.

BICUDO, M. A. V. Fenomenologia: confrontos e avanços. São Paulo: Cortez, 2000.

BICUDO, M. A. V.; ESPÓSITO, V. H. Cunha. Joel Martins...um seminário avançado em fenomenologia. São Paulo: Educ, 1997.

BICUDO, M. A. V. Pesquisa qualitativa segundo a visão fenomenológica. São Paulo: Cortez, 2011.

BOGDAN, R.; BIKLEN, S. K. Investigação Qualitativa em Educação: uma introdução à teoria e aos métodos, Porto: Porto editora, 1985

CERBONE, D. R. Fenomenologia. 3. ed. Petrópolis: Vozes, 2014.

CLANDININ, D. J.; CONELLY, F. M. Narrative inquiry: experience and story in qualitative research. San Francisco: Jossey-Bass, 2000. 
DEMO, P. Educar pela Pesquisa. Campinas: Editora Autores Associados, 1996.

DENZIN, N. K.; LINCOLN, Y. S. (ed.). Handbook of qualitative research. Thousand Oaks, CA: Sage, 1994.

DENZIN, N. K.; LINCOLN, Y. S. O planejamento da pesquisa qualitativa: teorias e abordagens. Trad. Sandra Regina Netz. 2. ed. Porto Alegre: Artmed, 2006.

ENGERS, M. E. Paradigmas e Metodologias de Pesquisa em Educação: notas para reflexão. Porto Alegre: Edipucrs, 1994.

GADAMER, Hans-Georg. Da palavra ao conceito. In: ALMEIDA, C. L. S. de; FLICKINGER, Hans-Georg; ROHDEN, L. Hermenêutica Filosófica: nas trilhas de Hans-Georg Gadamer. Porto Alegre: EDIPUCRS, 2000. p. 13-26.

GADAMER, Hans-Georg. Verdade e método I: traços fundamentais de uma hermenêutica filosófica. 6. ed. Petrópolis: Vozes, 2004.

GADAMER, Hans-Georg. Verdade e método II: complementos e índice. 6. ed. Petrópolis: Vozes, 2004.

GALIAZZI, M. do C.; SOUSA, R. S. de. O que é isso que se mostra: o fenômeno na ATD? Atos de Pesquisa em Educação, Blumenau, v. 15, n. 3, 2020, (no prelo).

GALIAZZI, M. do C.; SOUSA, R. S. de. A dialética na categorização da análise textual discursiva: o movimento recursivo entre palavra e conceito. Revista Pesquisa Qualitativa, São Paulo, v. 7, n. 13, p. 1-22, abr. 2019.

GIORGI, A. Sobre o método fenomenológico utilizado como modo de pesquisa qualitativa nas ciências humanas: teoria, prática e avaliação. In: POUPART, J. et al. A Pesquisa Qualitativa. Trad. Ana Cristina Nasser. 4. ed. Petrópolis: Vozes, 2014. p. 386-409.

GRONDIN, J. Introdução à Hermenêutica filosófica. São Leopoldo: Editora Unisinos, 1999.

HERMANN, N. Autocriação e horizonte comum. Ijuí: Editora Unijuí, 2010.

KRIPPENDORFF, K. Metodologia de Análises de Contenido: teoria e práctica. Barcelona: Paidós, 1990.

LAKOFF, G.; JOHNSON, M. Metáforas da vida cotidiana. Coordenação da tradução de Mara Sofia Zanotto. Campinas, SP: Mercado das Letras; São Paulo: Educ. 2002

LINCOLN, Y. S.; GUBA, E. G. Naturalistic inquiry. Londres: Sage, 1985.

MARQUES, M. O. Escrever é preciso: o princípio de pesquisa. Ijuí: Unijuí, 1997.

MARTINS, J.; BICUDO, M. A. V. Estudos sobre existencialismo, fenomenologia e educação. 2. ed. São Paulo: Centauro, 2006.

METZLER, A. M. C; CARPENA, L. B.; BORGES, R. M. R. Fenomenologia como Filosofia e como Método de Investigação em Pesquisas Educacionais. In: ENGERS, M. E. Paradigmas e Metodologias de Pesquisa em Educação: notas para reflexão. Porto Alegre: Edipucrs, 1994. p. 75-83. 
MINAYO, M. C. de S. A Turbulenta Origem da Pesquisa Qualitativa no Brasil, In: SEMINÁRIO INTERNACIONAL DE PESQUISA E ESTUDOS QUALITATIVOS, 5., 2018, Foz de Iguaçu. Anais... Foz do Iguaçu: SE\&PQ, 2018. s.p.

MORAES, R. A educação de professores de ciências: uma investigação da trajetória de profissionalização de bons professores. 1991. Tese (Doutorado em Educação) - Faculdade de Educação, Universidade Federal do Rio Grande do Sul, Porto Alegre, 1991.

MORAES, R. Análise de Conteúdo, In: ENGERS, M. E. Paradigmas e Metodologias de Pesquisa em Educação: notas para reflexão. Porto Alegre: Edipucrs, 1994. p. 103-111.

MORAES, R. Análise de conteúdo. Educação, Porto Alegre, v. 22, n.37, p. 7-32, mar. 1999.

MORAES, R. No ponto final a clareza do ponto de interrogação inicial: a construção do objeto de uma pesquisa qualitativa. Educação, Porto Alegre, v. 25, n. 46, p. 231-248, 2002.

MORAES, R. Uma tempestade de luz: a compreensão possibilitada pela análise textual discursiva. Ciência \& Educação, Bauru, v. 9, n. 2, p. 191-211, 2003. Disponível em: $<$ http://www.scielo.br/scielo.php?script=sci_arttext\&pid=S1516-

73132003000200004\&lng=en\&nrm=iso> Acesso em: 20 ago. 2018.

MORAES, R.; GALIAZZI, M. do C. Análise textual discursiva: processo reconstrutivo de múltiplas faces. Ciência \& Educação, Bauru, v. 12, n. 1, p. 117-128, abr. 2006. Disponível em: $<$ http://www.scielo.br/scielo.php?script=sci_arttext\&pid=S1516-

$73132006000100009 \& \operatorname{lng}=\mathrm{en} \& n \mathrm{~nm}=\mathrm{iso}>$. Acesso em: 21 ago. 2018

MORAES, R.; GALIAZZI, M. do C. Análise Textual Discursiva. Ijuí: Editora Unijuí, 2007.

MORAES, R.; GALIAZZI, M. do C. Análise Textual Discursiva. 2. ed. Ijuí: Editora Unijuí, 2011.

MORAES, R.; GALIAZZI, M. do C. Análise Textual Discursiva. 3. ed. Revisada e Ampliada. Ijuí: Editora Unijuí, 2016.

MORAES, R. Percursos de Formação de Professores de Ciências: histórias de formação e profissionalização. Curitiba: Appris, 2019.

MORIN, E. O método I: A natureza da natureza. 2. ed. Lisboa: Publicações Europa-América, 1977.

MORIN, E. O método III: O conhecimento do Conhecimento. Lisboa: Publicações EuropaAmérica, 1986.

MORIN, E. A cabeça bem feita: repensar a reforma. reformar o pensamento. 2. ed. Rio de Janeiro: Bertrand do Brasil, 2000.

NEVES, M. C. D. An Ideographic and Nomothetic Comprehension of the Nature of Science by Science Teachers, Acta Scientiarum, Maringá, v. 21, n.1, p. 107-112, 1999.

OLABUENAGA, J. I. R.; ISPIZUA, M. A. La descodificación de la vida cotidiana: métodos de investigación cualitativa. Bilbao: Universidad de Deusto, 1989.

ORTEGA, F. J. R.; ALZATE, Ó. E. T.; BARGALLÓ, C. M. La argumentación em classe de ciências: um modelo para su enseñanza. Educação e Pesquisa, São Paulo, v. 41, n. 3, p. 629 646, sep. 2015. 
PERELMAN, C.; OBRECHTS-TYTECA, L. Tratado da argumentação. A nova retórica. São Paulo: Martins Fontes,1996.

RAMOS, M. G.; MORAES, R., Análise de características e comportamentos docentes de professores de Química de $3^{\circ}$ Grau. Educação, Porto Alegre, v. VIII, n. 9, p. 69-81, 1985.

RAMOS, M. G.; MORAES, R. Análise de problemas de Ensino de docentes de Química de $3^{\circ}$ grau. Educação, Porto Alegre, v. IX, n. 11, p. 85-97, 1986.

RAMOS, M. G. Avaliação do desempenho docente numa perspectiva qualitativa: contribuições para o desenvolvimento profissional de professores no ensino superior. Tese (Doutorado em Educação) - Faculdade de Educação, Pontifícia Universidade Católica do Rio Grande do Sul, Porto Alegre, 1999.

RAMOS, M. G.; GALIAZZI, M. do C. Aprendentes do aprender: um exercício de análise textual discursiva. Indagatio Didactica, Aveiro, v. 5, n. 2, p. 962-882, oct. 2013.

RAMOS, M. G.; LIMA, V. M. do R. de.; GESSINGER, R. M. Metanálise dos processos analíticos presentes em dissertações de um programa de pós-graduação em Educação em Ciências e Matemática. Indagatio Didactica, Aveiro, v. 6, n. 3, p. 125-139, ago. 2014.

REASON, P.; ROWAN, J. (ed.). Human Inquiry: A Sourcebook of New Paradigm Research. New York: John Wiley and Sons, 1981.

RICOEUR, P. Metáfora Viva. São Paulo: Edições Loyola, 2000.

ROHDEN, L. Hermenêutica filosófica: entre a linguagem da experiência e a experiência da linguagem. São Leopoldo: Unisinos, 2002.

SANTOS, B. de S. S. Um discurso sobre as ciências. Porto: Afrontamento, 1987.

SIMON, S.; ERDURAN, S.; OSBORNE, J. Learning to teach argumentation: research and development in the Science classroom. International Journal of Science Education, London, v. 28, n. $2 / 3$, p. $235-260$, fev. 2007

SOUSA, R. S.; GALIAZZI, M. do C. A categoria na análise textual discursiva: sobre método e sistema em direção à abertura interpretativa. Revista Pesquisa Qualitativa, São Paulo, v. 5, n. 9 , p. 514-538, dez. 2017a.

SOUSA, R. S.; GALIAZZI, M. do C. Compreensões acerca da hermenêutica na análise textual discursiva: marcas teórico-metodológicas à investigação. Revista Contexto \& Educação, Ijuí, v. 31 , n. 100 , p. $33-55,2017 \mathrm{~b}$.

SOUSA, R. S.; GALIAZZI, M. do C. O jogo da compreensão na Análise Textual Discursiva. Ciência \& Educação, Bauru, v. 24, n. 3, p. 799-814, 2018.

St PIERRE, E. A. Uma história breve e pessoal da pesquisa pós-qualitativa: em direção à "pósinvestigação". Práxis Educativa, Ponta Grossa, v. 13, n.3, p. 1044-1064, set./dez. 2018.

WARSCHAUER, C. Rodas em rede: oportunidades formativas na escola e fora dela. Rio de Janeiro: Paz e Terra, 2001.

WELLS, G. Dialogic inquiry: towards a sociocultural practice and theory of education. New York: Cambridge University Press, 1999. 
WELLS, G. Action, Talk and Text: learning and teaching through Inquiry, Teachers College Press, 2001.

WERTSCH, J. V.; DEL RÍO, P.; ALVAREZ, A. Estudos socioculturais da mente. Porto Alegre: Artmed, 1998.

Recebido em: 31 de outubro de 2020.

Aceito em: 10 de novembro de 2020. 